\title{
Revising Fiscal Policy and Growth in Saudi Arabia
}

\author{
Janelle Mann ${ }^{1, *}$ and Peter Sephton ${ }^{2}$ \\ ${ }^{1}$ Department of Economics, University of Manitoba, Canada \\ ${ }^{2}$ School of Business, Queen's University, Canada
}

\begin{abstract}
This article empirically investigates how private investment and different categories of public expenditure (defense, education, health care, and housing) impact real non-oil GDP in Saudi Arabia. The econometric analysis couples unit root, stationarity, and cointegration analysis with vector error correction models. Impulse response functions are applied to examine the impacts of different shocks to the system. We find that public expenditures on health care and defense have decreased real non-oil GDP while public expenditure on education and housing have very little impact. Interestingly, public expenditures on health crowds-out private investment.
\end{abstract}

Keywords: Fiscal Policy, Cointegration, Vector Error Correction Model, Impulse Response Function.

\section{INTRODUCTION}

One of the ways in which to measure the efficacy of a nation's fiscal policies is to examine the sign and magnitude of the impact of public expenditure on GDP (Marattin and Salotti 2014). In this article we employ a variety of methods to investigate the impact of public expenditure on real non-oil GDP in Saudi Arabia between 1971 and 2012. We begin by reporting how aggregated public expenditures impact real non-oil GDP, after which we report that four specific categories of public spending have very different implications for the economy.

Empirical evidence on the impacts of different categories of fiscal spending indicate that defense spending tends to have a negative impact on GDP (Shahbaz, Afza, and Shabbir 2013; Chang, Lee, and Chu 2013; Al-Jarrah 2005) while that on healthcare tends to have a neutral to positive impact on GDP (Ozturk and Topcu 2014; Tang 2012; Mehrara and Musai 2011; Baldacci and others 2004). Education spending has been reported to have a positive impact (Alshahranin and Alsadiq 2014; Hussin, Muhammad, Abu, and Razak 2012; Baldacci and others, 2004) while housing or infrastructure spending appears to have a neutral to positive impact (Alshahranin and Alsadiq 2014; Fedderke and others 2006; AlbalaBertrand and Mamatzakis 2001; Baffes and Shah 1998).

Our empirical analysis provides evidence that public expenditure on defense has a negative impact on real non-oil GDP. Surprisingly, spending on housing and

\footnotetext{
*Address correspondence to this author at the Department of Economics, University of Manitoba, 556 Fletcher Argue Building, Winnipeg, Manitoba, R3T 2N2, Canada; Tel: (204) 474-9275; Fax: (204) 474-9207;

E-mail: janelle.mann@umanitoba.ca
}

education does not appear to be directly linked to nonoil economic growth. Unlike previous studies, we report that health spending appears to be negatively related to economic activity. This latter result may be attributed to a crowding-out of private sector investment. The empirical analysis provides three key insights for Saudia Arabian fiscal policy makers: (1) there is a longrun relationship between public expenditure variables and non-oil GDP, (2) policy makers should critically evaluate their methods of allocating government expenditures to health care, and (3) trade enhancing policies have a positive impact on non-oil real GDP.

\section{DATA AND ECONOMETRIC ANALYSIS}

We employ the natural logarithms of annual data from 1971 through 2012 for a variety of economic series: per capita real non-oil GDP (NO-PCGDP), private investment (PRIVATEI), oil revenue (OILREV), openness to trade (TRADE) proxied by the sum of imports and exports, total capital expenditure (CAPITAL), total current expenditure (CURRENT), defence expenditure (DEFENCE), education expenditure (EDUCATION), health expenditure (HEALTH), and housing and community amenities expenditure (HOUSING). All variables were collected from the Annual Statistics report from the Saudi Arabian Monetary Agency (2014). Series were converted into real terms using 1999 as the base year.

The first stage of our analysis is to determine the order of integration for each series. We employed the GLS-ADF unit root test (Elliott, Rothenberg, and Stock 1996) and the efficient fractional DF unit root test (Lobato and Velasco 2007) with critical values simulated following Sephton (2009) to determine whether the series were I(1) or not. If the series are integrated of the same order we will perform a test for 
cointegration to see if there is at least one long-run attractor to which the system will return when perturbed. We will use the Johansen Trace test (Johansen 1988, 1995) and critical values corrected for the sample size following Doornik (1998).

Our first model investigates the long run relationships between NO-PCGDP, PRIVATEI, OILREV, TRADE, CAPITAL, and CURRENT. This is an attempt to measure, at a relatively high level of aggregation, the impacts of capital and current spending on economic activity. The second model disaggregates fiscal expenditures into four separate categories (DEFENSE, EDUCATION, HEALTH, and HOUSE) to capture their different impacts on the temporal evolution of real non-oil GDP.

The third step of the econometric analysis, conditional on a finding of cointegration, is to estimate a vector error correction model (VECM). Impulse response functions with bootstrapped confidence intervals allow us to analyze how different shocks impact the behaviour of the system both in terms of their immediate impacts, and how the relationships evolve over time. A full understanding of the system is necessary in order to make fiscal policy recommendations with desirable impacts. The dominant role of the public sector in Middle-Eastern countries heightens the level of importance (Abu-Bader and Abu-Qarn 2003).

\section{DISCUSSION OF RESULTS}

According to results of the GLS-ADF and efficient fractional DF tests each series appears to be nonstationary and I(1), a finding which concurs with Alshanhrani and Alsadiq (2014). The Johansen Trace test results suggest that for both the aggregated and disaggregated models, there are four long-run attractors drawing the series together over time. For brevity we did not include these results in a table, but they are available upon request.

The estimated VECM for the aggregated measure of fiscal expenditures model (Model 1) is reported in

Table 1: VECM for Model 1

\begin{tabular}{|c|c|c|c|c|}
\hline & $\triangle N O-P C G D P_{t}$ & $\triangle P R I V A T E I_{\mathrm{t}}$ & $\triangle O^{\prime L R E V} V_{\mathrm{t}}$ & $\triangle T R A D E_{\mathrm{t}}$ \\
\hline$\Delta N O-P C G D P_{\mathrm{t}-1}$ & 0.091 & 0.719 & 0.188 & 0.007 \\
\hline$\triangle P R I V A T E I_{\mathrm{t}-1}$ & $-0.151^{* *}$ & 0.025 & 0.306 & 0.059 \\
\hline$\Delta O I L R E V_{\mathrm{t}-1}$ & $-0.061^{*}$ & -0.133 & 0.054 & 0.069 \\
\hline$\Delta T R A D E_{\mathrm{t}-1}$ & $0.185^{*+* *}$ & 0.274 & 0.883 & 0.350 \\
\hline$\triangle C A P I T A L_{\mathrm{t}-1}$ & -0.005 & 0.008 & -0.028 & 0.007 \\
\hline$\triangle C U R R E N T_{\mathrm{t}-1}$ & $0.080^{*}$ & 0.155 & 0.222 & 0.110 \\
\hline$E C 1_{t-1}$ & $-0.425^{* * * *}$ & 0.246 & -0.417 & -0.318 \\
\hline $\mathrm{EC} 2{ }_{\mathrm{t}-1}$ & $0.222^{* * * *}$ & $-0.554 \star *$ & 0.791 & $0.451^{*}$ \\
\hline $\mathrm{EC}_{\mathrm{t}-1}$ & $0.110^{* *}$ & -0.141 & $-0.909^{* *}$ & 0.068 \\
\hline \multirow[t]{2}{*}{$\mathrm{EC4}_{\mathrm{t}-1}$} & -0.120 & $0.587^{* *}$ & 0.598 & -0.393 \\
\hline & $\triangle C A P I T A L_{\mathrm{t}}$ & $\triangle$ CURRENT $_{\mathrm{t}}$ & & \\
\hline$\Delta N O-P C G D P_{\mathrm{t}-1}$ & -5.803 & $2.519^{* * * *}$ & & \\
\hline$\triangle P R I V A T E I_{\mathrm{t}-1}$ & 0.907 & 0.090 & & \\
\hline$\Delta O I L R E V_{\mathrm{t}-1}$ & 0.049 & 0.201 & & \\
\hline$\triangle T R A D E_{\mathrm{t}-1}$ & 2.248 & -0.092 & & \\
\hline$\triangle C A P I T A L_{\mathrm{t}-1}$ & 0.269 & -0.006 & & \\
\hline$\Delta C U R R E N T_{\mathrm{t}-1}$ & 0.355 & 0.087 & & \\
\hline$E C 1_{t-1}$ & $6.310^{* * * t}$ & 0.608 & & \\
\hline$E C 2_{t-1}$ & -1.301 & -0.249 & & \\
\hline $\mathrm{EC}_{\mathrm{t}-1}$ & -0.056 & $-0.845_{* \star *}$ & & \\
\hline$E C 4_{t-1}$ & 1.077 & $0.982 * *$ & & \\
\hline
\end{tabular}

NOTE: Dependent variable listed in first row. Significance at $\alpha=0.10,0.05$ and 0.01 denoted ", and "*.". 
Table 2: VECM for Model 2

\begin{tabular}{|c|c|c|c|c|}
\hline & $\triangle N O-P C G D P_{\mathrm{t}}$ & $\triangle P R I V A T E I_{\mathrm{t}}$ & $\triangle$ OILREV $_{\mathrm{t}}$ & $\triangle T R A D E_{\mathrm{t}}$ \\
\hline$\Delta N O-P C G D P_{\mathrm{t}-1}$ & 0.079 & 0.766 & -1.421 & -0.693 \\
\hline$\triangle P R I V A T E I_{\mathrm{t}-1}$ & -0.141 & -0.352 & 0.864 & 0.221 \\
\hline$\triangle O I L R E V_{\mathrm{t}-1}$ & 0.027 & -0.175 & 0.362 & 0.209 \\
\hline$\triangle T R A D E_{\mathrm{t}-1}$ & 0.065 & 0.130 & -0.262 & -0.149 \\
\hline$\Delta D E F E N S E_{\mathrm{t}-1}$ & -0.068 & $0.624^{* *}$ & -0.443 & -0.116 \\
\hline$\triangle E D U C A T I O N_{\mathrm{t}-1}$ & $0.335^{* *}$ & -0.706 & -0.389 & 0.019 \\
\hline$\Delta H E A L T H_{\mathrm{t}-1}$ & $-0.171^{* *}$ & 0.218 & 0.331 & 0.109 \\
\hline$\triangle H O U S E_{-1}$ & 0.022 & 0.065 & 0.053 & -0.013 \\
\hline$E C 1_{t-1}$ & $-0.239^{* * *}$ & 0.023 & $0.690^{*}$ & -0.022 \\
\hline$E C 2_{t-1}$ & 0.024 & 0.121 & 0.137 & 0.097 \\
\hline $\mathrm{EC}_{\mathrm{t}-1}$ & -0.004 & -0.098 & $-1.284_{* \star *}$ & -0.138 \\
\hline \multirow[t]{2}{*}{$E C 4_{t-1}$} & 0.115 & 0.008 & $1.307^{* *}$ & 0.103 \\
\hline & $\triangle D E F E N S E_{\mathrm{t}}$ & $\triangle E D U C A T I O N_{\mathrm{t}}$ & $\triangle H E A L T H_{\mathrm{t}}$ & $\Delta$ HOUSE $_{\mathrm{t}}$ \\
\hline$\Delta N O-P C G D P_{\mathrm{t}-1}$ & -0.047 & 1.021 & 1.775 & 2.372 \\
\hline$\triangle P R I V A T E I_{\mathrm{t}-1}$ & -0.195 & -0.318 & -0.560 & -0.914 \\
\hline$\Delta O I L R E V_{\mathrm{t}-1}$ & -0.078 & -0.194 & -0.581 & -0.921 \\
\hline$\Delta T R A D E_{\mathrm{t}-1}$ & 0.075 & 0.261 & 0.980 & 1.507 \\
\hline$\Delta D E F E N S E_{\mathrm{t}-1}$ & 0.409 & 0.487 & 0.511 & 0.399 \\
\hline$\triangle E D U C A T I O N_{\mathrm{t}-1}$ & -0.634 & -0.126 & 0.462 & 0.840 \\
\hline$\Delta H E A L T H_{\mathrm{t}-1}$ & 0.414 & -0.200 & -0.409 & -0.334 \\
\hline$\Delta H O U S E_{\mathrm{t}-1}$ & -0.122 & -0.075 & -0.411 & -0.617 \\
\hline$E C 1_{t-1}$ & 0.204 & -0.100 & -0.802 & -1.759 \\
\hline$E C 2_{t-1}$ & -0.070 & 0.137 & 0.466 & 0.827 \\
\hline$E C 3_{t-1}$ & -0.314 & -0.333 & 0.058 & 0.155 \\
\hline$E C 4_{t-1}$ & 0.504 & 0.313 & -0.393 & -0.615 \\
\hline
\end{tabular}

NOTE: Dependent variable listed in first row. Significance at $\alpha=0.10,0.05$ and 0.01 denoted "," and "'.".

Table 1 while that for the disaggregated specification (Model 2) is in Table 2. The empirical results are quite different. When using aggregate measures of capital and current expenditures, we find that both series help the system to return to balance when it is perturbed. If we attempt to examine how different categories of spending impact the relationships, our measures of fiscal policy have no role in re-establishing equilibrium.

Impulse response functions for real non-oil GDP in response to a one standard deviation shock in other variables are presented in Figures 1 and $\mathbf{2}$ for Models 1 and 2, respectively. Unlike Joharji and Starr (2010) and Alshahranin and Alsadiq (2014), our results suggest that output weakly responds to shocks to capital expenditures, while it is negatively impacted by a shock to current fiscal spending.
The impulse response functions from Model 2 provide evidence that public expenditures on defense had a negative impact on output, while shocks to spending on education and housing had very little impact. Shocks to health care expenditure had a negative impact on real non-oil GDP, perhaps due to a crowding-out impact on private investment. This can be seen in the impulse response function for private investment in response to a one standard deviation shock in health care expenditures which is presented in Figure 3. This anomalous finding is also documented by Mohammadi, Maleki, and Gashti (2012) for economic co-operation organization countries. This finding is particularly troubling in the case of Saudi Arabia because per capita demand for health care services is forecasted to sharply increase by 2025 
Shock in PRIVATEI

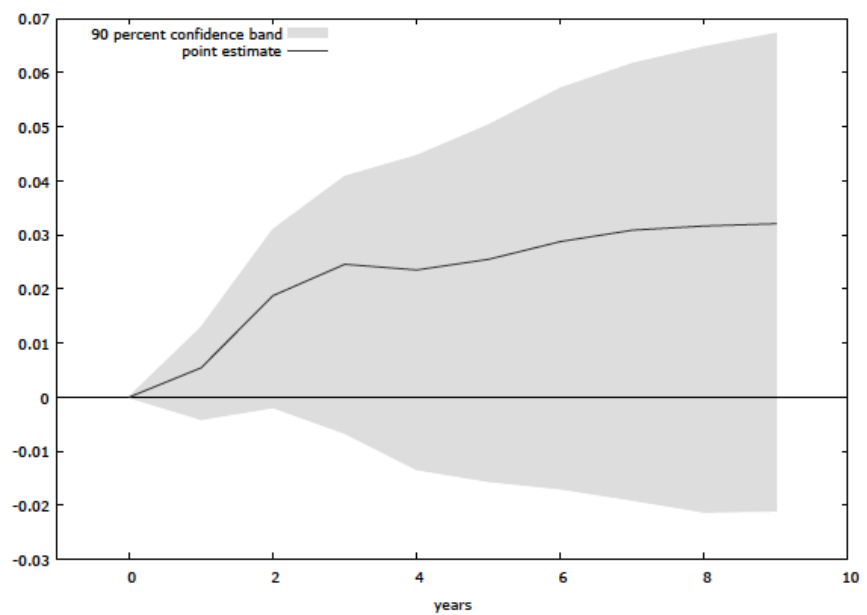

Shock in OPEN

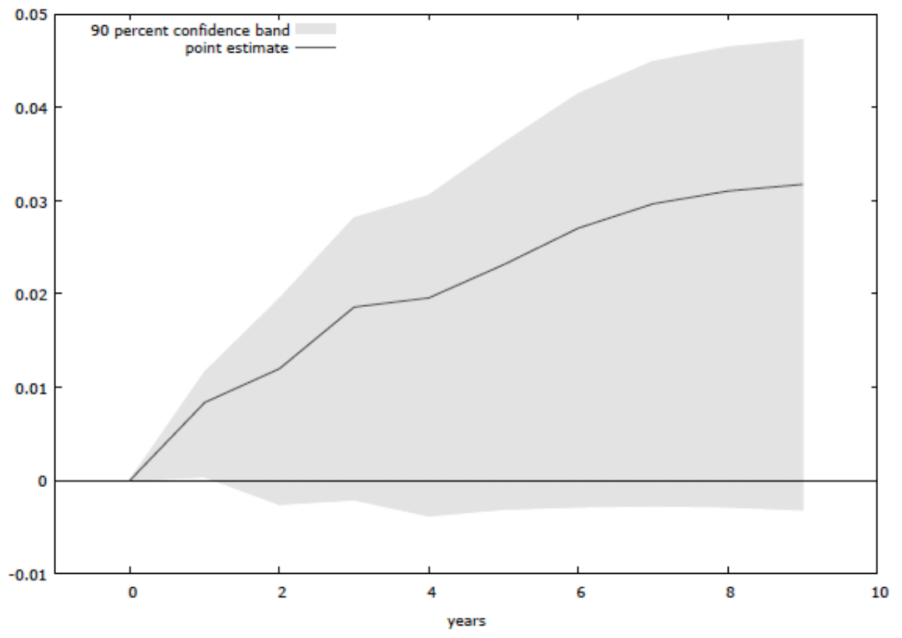

Shock in OILREV

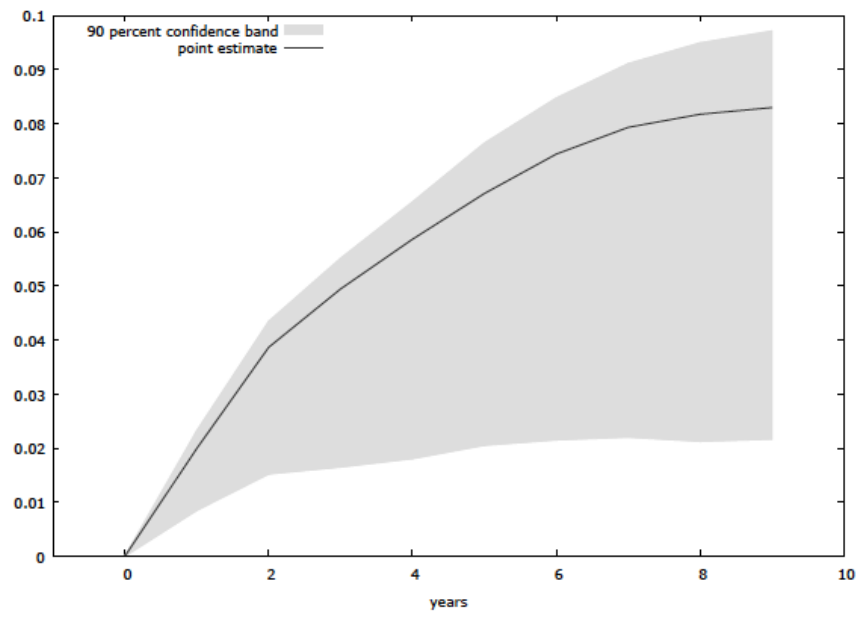

Shock in CURRENT

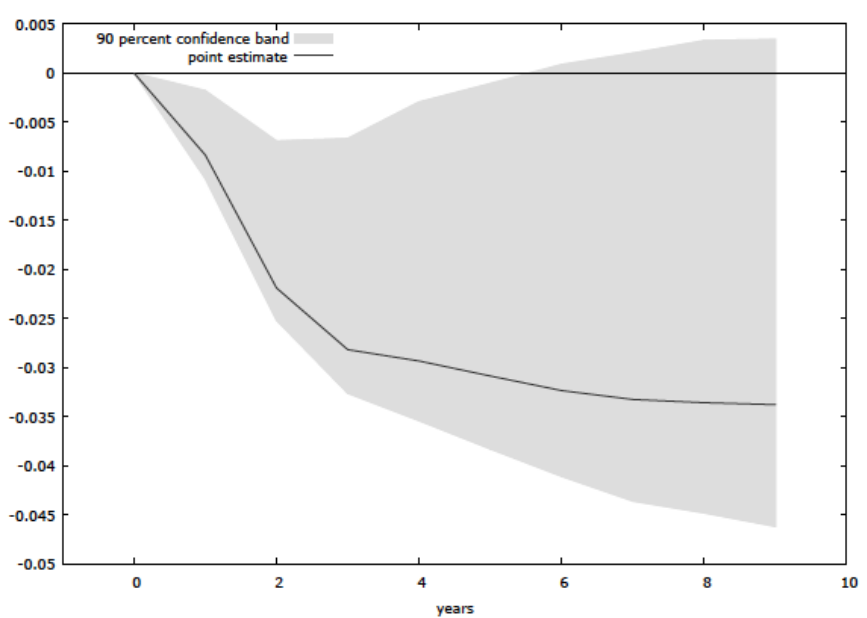

Shock in CAPITAL

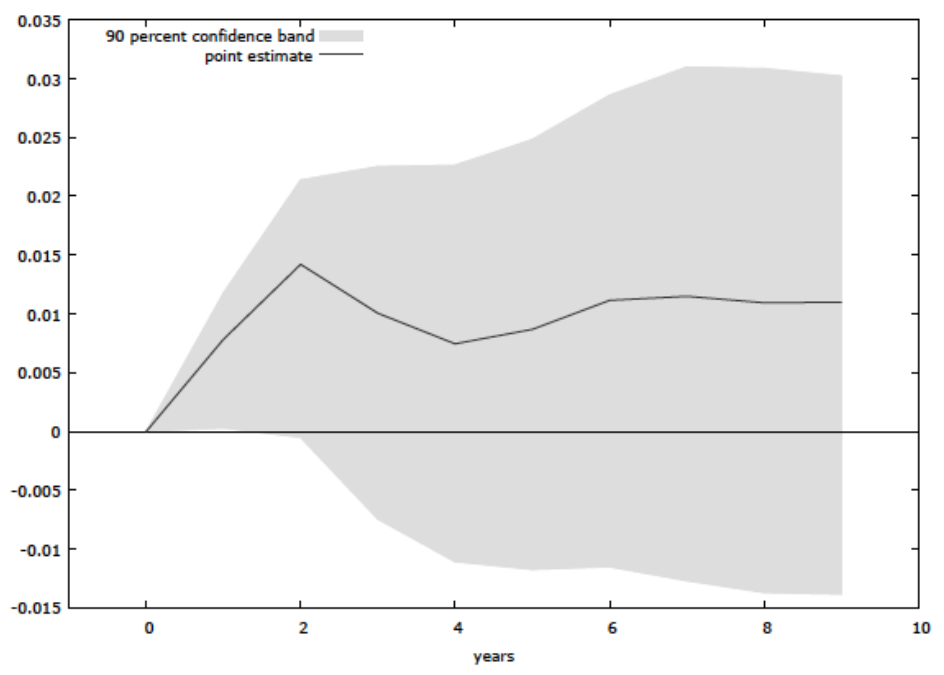

Figure 1: Impulse Response Functions for Per Capita Real Non-Oil GDP for Model 1.

NOTE: Gray shaded area depicts the $90 \%$ bootstrap confidence interval. 
Shock in PRIVATEI

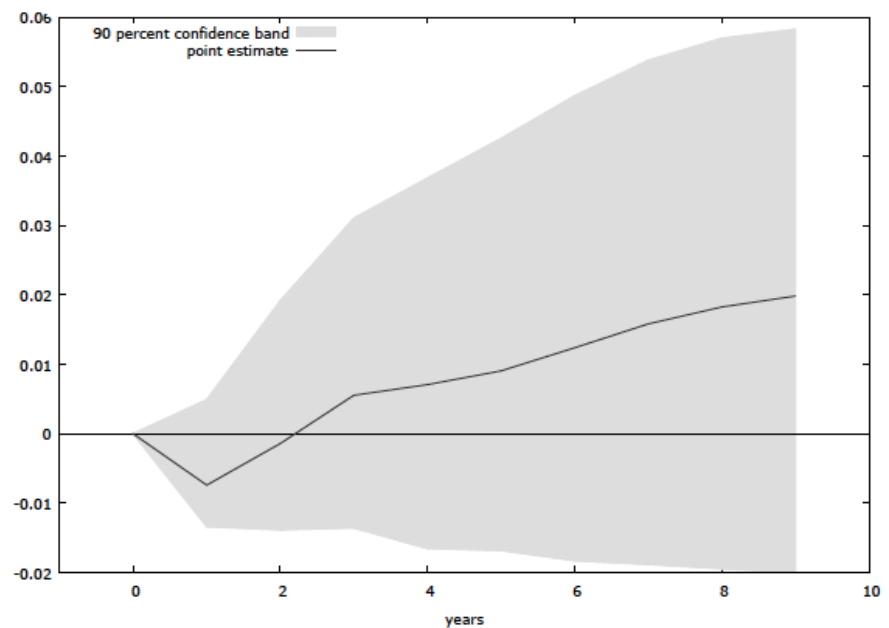

Shock in OILREV

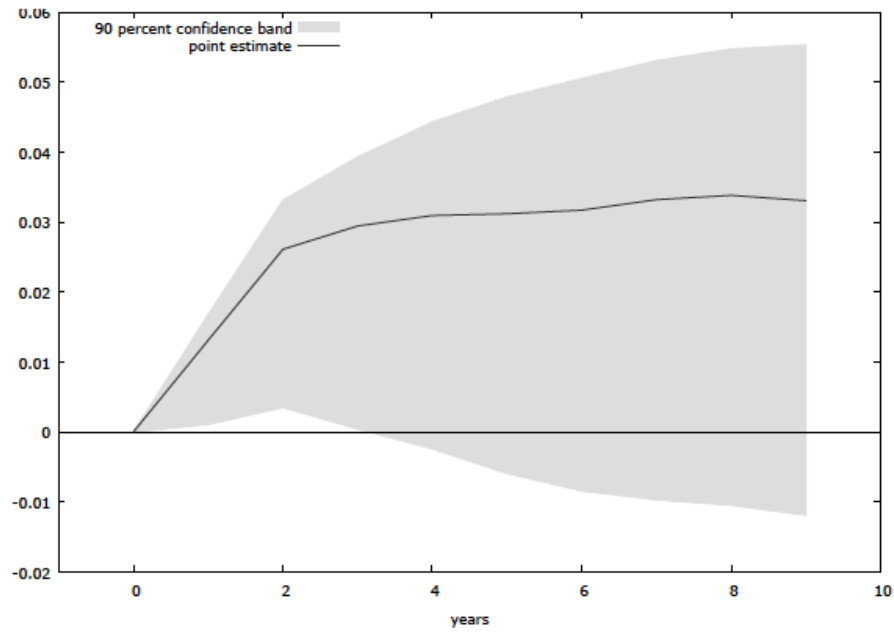

Shock in EDUCATION

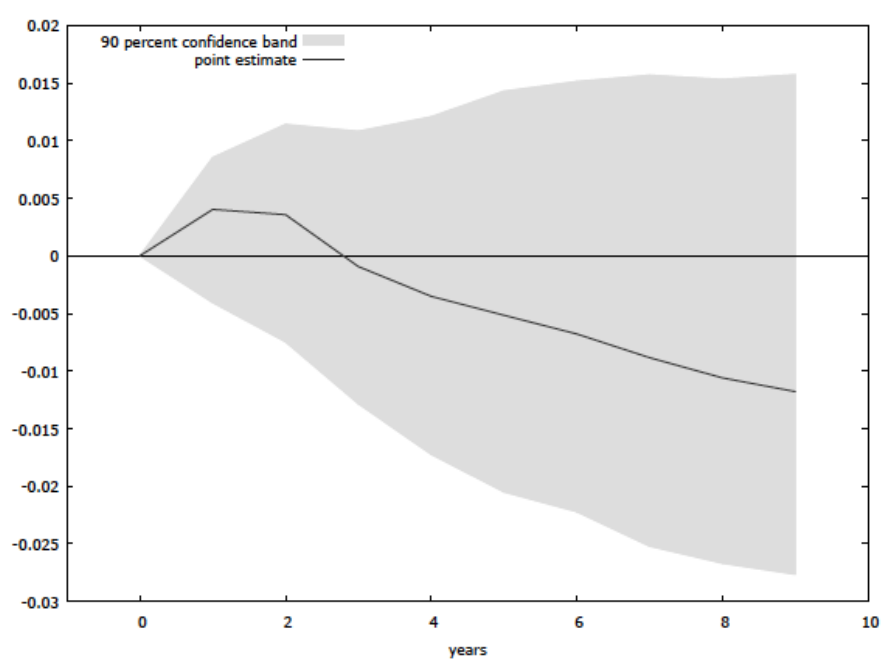

Shock in $O P E N$

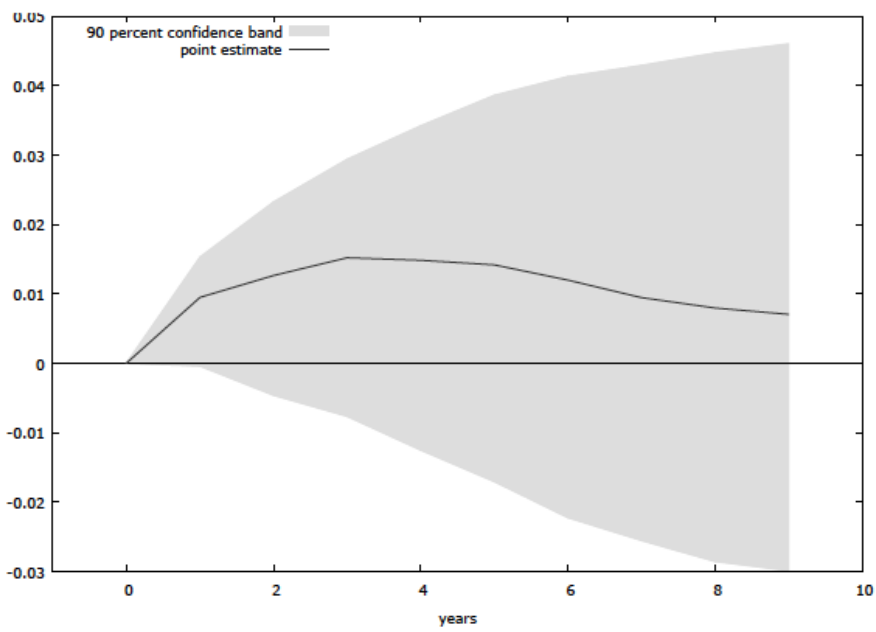

Shock in DEFENSE

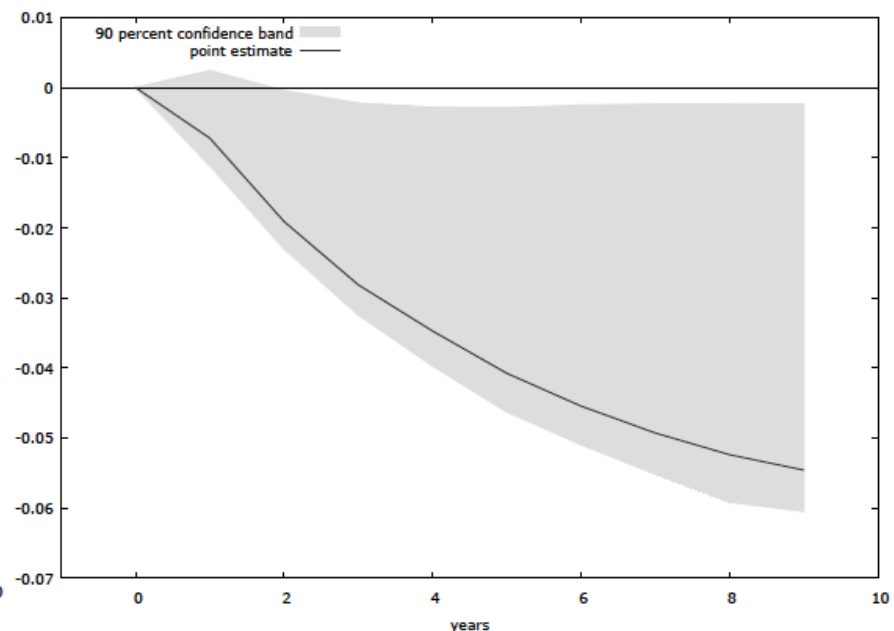

Shock in HEALTH

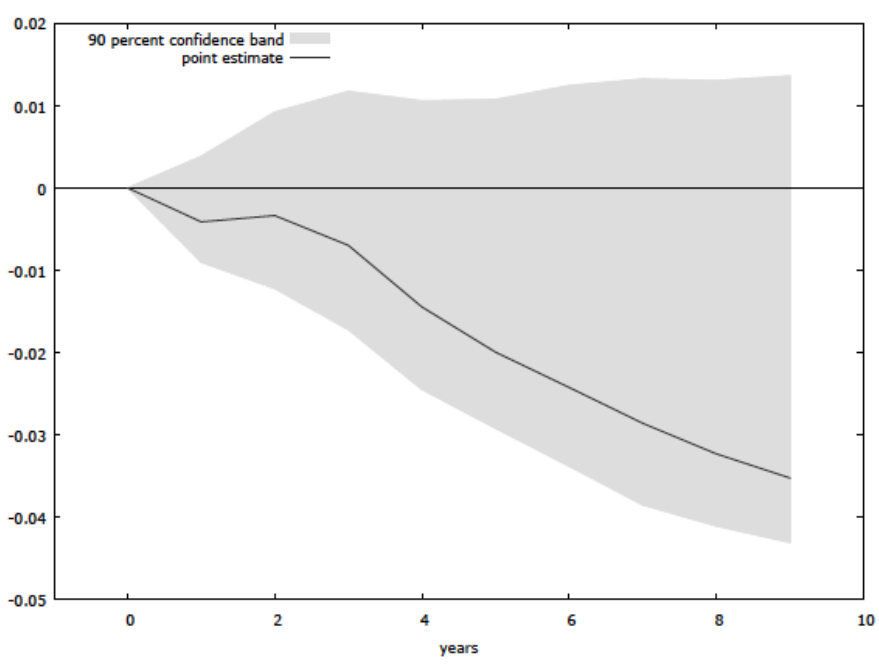


(Figure 2). Continued.

\section{Shock in HOUSE}

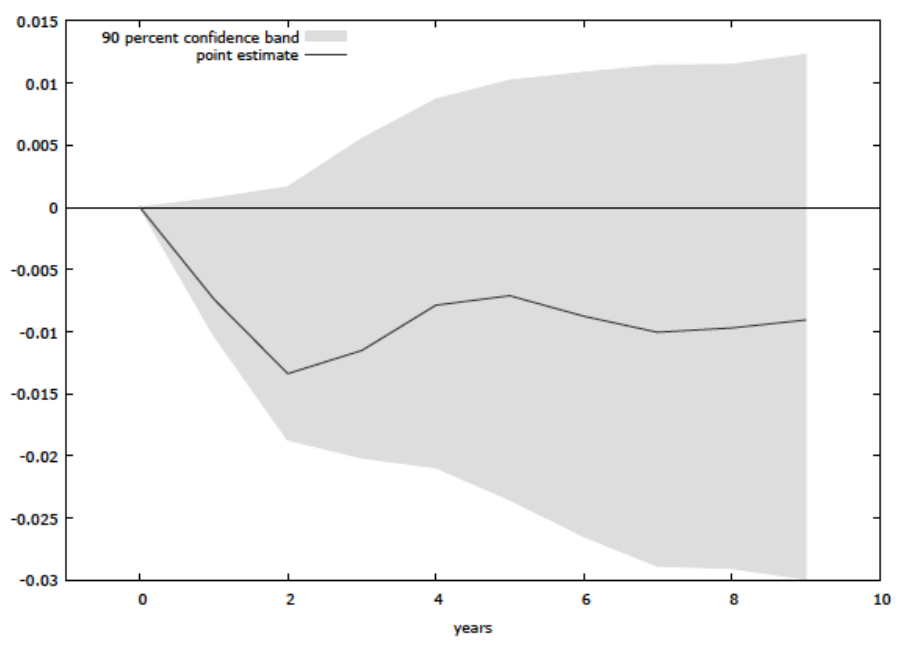

Figure 2: Impulse Response Functions for Per Capita Real Non-Oil GDP for Model 2.

NOTE: Gray shaded area depicts $90 \%$ bootstrap confidence interval.

(Watts 2014). Further probing reveals that two of the goals of a ten-year strategic healthcare plan approved by Saudi Arabia in 2009 are to diversify funding and encourage the public sector in the delivery of services (Watts 2014). In order to achieve these goals policy makers should critically evaluate their methods of allocating government expenditures to healthcare in order to avoid the crowding-out of private investment. Within the ten-year strategic healthcare plan the role of the government in the current healthcare model is already being questioned. Policy makers have started to change how they allocate government expenditures. They recently revised their public-private partnership

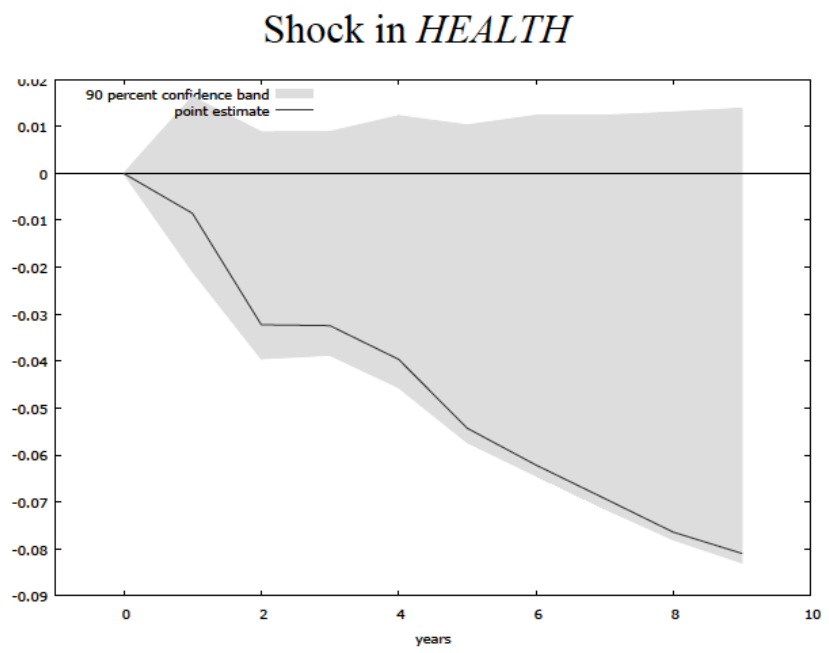

Figure 3: Impulse Response Function for Private Investment for Model 2.

NOTE: Gray shaded area depicts the $90 \%$ bootstrap confidence interval. model and are partially subsidizing loans for local companies building healthcare infrastructure (Watts 2014).

The impulse response functions from Model 2 also provide evidence that government expenditure on housing neither crowds-in nor crowds-out private investment. This result does not provide further insight into the Neoclassical argument for the complementarity nor substitutability of government expenditure and private investment (Wang 2005). The analysis includes periods of government debt build-up, particularly during periods of low oil prices, which resulted in a decrease in banks' lending ability (Wilson 2003). The crowdingout of private investment that is hypothesized by Keynesian economics may have been alleviated by combining expansionary fiscal policy with accommodating monetary policy (Wang 2005; Laopodis 2001).

Both Models 1 and 2 indicate that trade openness had a positive impact on non-oil GDP (assuming that trade volume is a valid proxy for trade openness). The stark difference between the models is the magnitude and the shape of the impact. The impact is smaller for the disaggregated data (Model 2) and plateaus with a gradual and slight decrease after the third year. This inverted-U finding concurs with Shahbaz and others (2013) for Portugal.

\section{CONCLUSIONS AND POLICY IMPLICATIONS}

This article empirically investigates how different categories of public expenditure (defense, education, 
health care, and housing) impact private investment and real non-oil GDP in Saudi Arabia. Due to mixed and inconclusive results from previous empirical studies it is imperative that governments research the relationship in their respective country prior to making fiscal policy decisions. This statement is true for Saudi Arabia because, despite the majority of findings being in-line with previous literature, the empirical findings revealed that government expenditure on health care had a negative impact on real non-oil GDP and crowded-out private investment. It follows that policy makers should critically evaluate their methods of allocating government expenditures to health care, especially due to the increasing per capita demand for health care. Saudi Arabia is currently in the fourth year of a ten-year strategic healthcare plan which makes it important to reinvestigate this finding to reveal whether changes being implemented to promote private investment are effective. Moreover, policy makers should be aware that results from both Models 1 and 2 find openness to trade increased real non-oil GDP. The aggregated model (Model 1) overestimated the increase; never-the-less the evidence suggests that policy makers should be aware that trade enhancing policies increase real non-oil GDP. These are important findings given the recent decline in oil prices and the associated shift in the composition of Saudi Arabia's economic activity. It is difficult not to view this in terms of a transition between the "take-off" and "drive to maturity" stages attributed to Rostow (1960). Trade enhancement can only hasten structural change, and it has the potential to mitigate the deleterious impacts of increased social spending on health care. Managing these competing forces is a Herculean task and it is clear that the authorities are up to the challenge.

\section{REFERENCES}

Abu-Bader, S. and A. S. Abu-Qar. 2003. "Government Expenditures, Military Spending and Economic Growth: Causality Evidence from Egypt, Israel, and Syria." Journal of Policy Modeling, 25(6): 567-583. http://dx.doi.org/10.1016/S0161-8938(03)00057-7

Albala-Bertrand, J. and E.C. Mamatzakis. 2001. "Is Public Infrastructure Productive? Evidence from Chile." Applied Economics Letters, 8(3), 195-198. http://dx.doi.org/10.1080/13504850150504595

Al-Jarrah, M. A. 2005. "Defense Spending and Economic Growth in an Oil-rich Country: The Case of Saudi Arabia." Pakistan Economic and Social Review, 43(2), 151-166.

Alshahrani, S. A. and A. J. Alsadiq. 2014. "Economic Growth and Government Spending in Saudi Arabia: An Empirical Investigation." International Monetary Fund.

Baffes, J. and A. Shah, A 1998. "Productivity of Public Spending, Sectoral Allocation Choices, and Economic Growth." Economic Development and Cultural Change, 46(2), 291303.
Baldacci, E., Q. Cui, B.J. Clements, and S. Gupta. 2004. "Social Spending, Human Capital, and Growth in Developing Countries: Implications for Achieving the MDGs." International Monetary Fund.

Chang, T., C. Lee, and H. Chu. 2013. "Revisiting the DefenseGrowth Nexus in European Countries." Defence and Peace Economics, 26(3): 341-356. http://dx.doi.org/10.1080/10242694.2013.832556

Doornik, J. A. 1998. "Approximations to the Asymptotic Distributions of Cointegration Tests." Journal of Economic Surveys, 12(5), 573-593. http://dx.doi.org/10.1111/1467-6419.00068

Elliott, G., T.J. Rothenberg, and J.H. Stock. 1996. "Efficient Tests for an Autoregressive Unit Root." Econometrica, 64(4), 813-836. http://dx.doi.org/10.2307/2171846

Fedderke, J. W., P. Perkins, and J.M. Luiz. 2006. "Infrastructural Investment in Long-Run Economic Growth: South Africa 1875-2001." World Development, 34(6), 1037-1059. http://dx.doi.org/10.1016/j.worlddev.2005.11.004

Hussin, M. Y. M., F. Muhammad, M.F. Hussin, and A. A. Razak. 2012. "Education Expenditure and Economic Growth: A Causal Analysis for Malaysia." Journal of Economics and Sustainable Development, 3(7), 71-81.

Johansen, S. 1995. "Likelihood-Based Inference in Cointegrated Vector Autoregressive Models." Oxford: Oxford University Press. http://dx.doi.org/10.1093/0198774508.001.0001

Johansen, S. 1988. "Statistical Analysis of Cointegration Vectors." Journal of Economic Dynamics and Control, 12(2), 231-254. http://dx.doi.org/10.1016/0165-1889(88)90041-3

Joharji, G. A. and M.A. Starr. 2010. "Fiscal Policy and Growth in Saudi Arabia." Review of Middle East Economics and Finance, 6(3), 1-22.

Laopodis, N. T. 2001. "Effects of Government Spending on Private Investment." Applied Economics, 33(12), 1563-1577. http://dx.doi.org/10.1080/00036840010011934

Lobato, I. N. and C. Velasco. 2007. "Efficient Wald tests for Fractional Unit Roots." Econometrica, 75(2), 575-589. http://dx.doi.org/10.1111/j.1468-0262.2006.00758.x

Marattin, L. and S. Salotti. 2014. "Consumption Multipliers of Different Types of Public Spending: A Structural Vector Error Correction Analysis for the UK." Empirical Economics, 46(4), 1197-1220. http://dx.doi.org/10.1007/s00181-013-0719-0

Mehrara, M. 2013. "The Causality between Human Capital and Economic Growth in Oil Exporting Countries: Panel Cointegration and Causality." Journal of Business Management \& Social Sciences Research, 2(6), 62-66.

Mehrara, M., and M. Musai. 2011. "Granger Causality between Health and Economic Growth in Oil Exporting Countries." Interdisciplinary Journal of Research in Business, 1(8), 103108.

Mohammadi, T., B. Maleki, and H.P. Gashti. 2012. "The Effect of Government Expenditure Composition on Economic Growth: Evidence on ECO Countries." Economics \& Finance Review, 2(5), 14-21.

Ozturk, S., and E. Topcu. 2014. "Health Expenditures and Economic Growth: Evidence from G8 Countries." International Journal of Economics and Empirical Research, 2(6), 256-261.

Rostow, W. W. 1960. "The Stages of Economic Growth: A NonCommunist Manifesto." Cambridge University Press.

Saudi Arabian Monetary Agency. 2014. Annual Statistics Report.

Sephton, P. S. 2009. "Critical Values for the Augmented Efficient Wald Test for Fractional Unit Roots." Empirical Economics, 37(3), 615-626. http://dx.doi.org/10.1007/s00181-008-0249-3

Shahbaz, M., T. Afza, and M.S. Shabbir. 2013. "Does Defence Spending Impede Economic Growth? Cointegration and 
Causality Analysis for Pakistan." Defence and Peace Economics, 24(2), 105-120.

http://dx.doi.org/10.1080/10242694.2012.723159

Shahbaz, M., N.C. Leitão, G.S. Uddin, M. Arouri, and F. Teulon. 2013. "Should Portuguese Economy Invest in Defense Spending? A Revisit." Economic Modelling, 35, 805-815. http://dx.doi.org/10.1016/j.econmod.2013.08.038

Tang, C. F. (2013). "A Note on the Health-Growth Nexus in Malaysia." Journal of Health Management, 15(3), 345-352. http://dx.doi.org/10.1177/0972063413491872
Wang, B. 2005. "Effects of Government Expenditure on Private Investment: Canadian Empirical Evidence." Empirical Economics, 30(2), 493-504. http://dx.doi.org/10.1007/s00181-005-0245-9

Watts, C. and A. Freudmann (eds.). 2014. "Healthcare in Saudi Arabia: Increasing Capacity, Improving Quality?" The Economist Intelligence Unit.

Wilson, R., A. Al-Salamah, M. Malik, and A. Al-Rajhi. 2012. "Economic Development in Saudi Arabia." London and New York: RoutledgeCurzon."

Received on 28-05-2015

Accepted on 17-06-2015

Published on 30-07-2015

DOI: http://dx.doi.org/10.6000/1929-7092.2015.04.13

(C) 2015 Mann and Sephton; Licensee Lifescience Global.

This is an open access article licensed under the terms of the Creative Commons Attribution Non-Commercial License (http://creativecommons.org/licenses/by-nc/3.0/) which permits unrestricted, non-commercial use, distribution and reproduction in any medium, provided the work is properly cited. 